\title{
The Dutch, the World Tallest Are Shrinking in the Latest Decade or So: The Lessons from the Case of South Korea and Japan in North-East Asia
}

\author{
Hiroshi Mori \\ Senshu University, Tokyo, Japan \\ Email: hymori@isc.senshu-u.ac.jp
}

How to cite this paper: Mori, H. (2022) The Dutch, the World Tallest Are Shrinking in the Latest Decade or So: The Lessons from the Case of South Korea and Japan in North-East Asia. Food and Nutrition Sciences, 13, 85-96.

https://doi.org/10.4236/fns.2022.131009

Received: December 28, 2021

Accepted: January 25, 2022

Published: January 28, 2022

Copyright (อ 2022 by author(s) and Scientific Research Publishing Inc.

This work is licensed under the Creative Commons Attribution-NonCommercial International License (CC BY-NC 4.0).

http://creativecommons.org/licenses/by-nc/4.0/

\section{(c) (i) \& Open Access}

\begin{abstract}
The Dutch have been the world tallest since the 1980s but plateaued in height for the past few decades. A century and a half ago, young men at 20 in the Netherlands were $165 \mathrm{~cm}$ in mean height, as tall as men in France and Portugal. They grew to $178 \mathrm{~cm}$, as tall as Norwegian in 1960 , and $183 \mathrm{~cm}$ in mean height in the 1990s and levelled off. It is most likely that the Dutch may have nearly attained genetic potential as a human being. The statue is a net measure that captures the supply of inputs to health. Based on the changes in per capita supply of protein from animal products, FAOSTAT, the Dutch seem to have reached the highest level in per capita supply of animal protein. Increases in the supply of protein, however, do not result in increasing human height, if consumption of other "essential nutrients" is insufficient (Blum, 2013; Mori, 2018) [1] [2]. With the close case studies of Japan and South Korea in respect of food consumption specifically by children in growing ages, the author suspects that children in the Netherlands may have been insufficient in the supply of vegetables, "essential nutrients" on the top of animal products.
\end{abstract}

\section{Keywords}

Men's Height, Growth Velocity, Netherlands, Animal Protein, Vegetables, Consumption by Age, South Korea

\section{Introduction}

A century and a half ago, young men (20 years of age) in the Netherlands were $165.3 \mathrm{~cm}$ tall in mean height, the same as French and $4 \mathrm{~cm}$ shorter than those in Norway. Toward the end of the century, the Dutch grew by $3 \mathrm{~cm}$ in height, 1.6 
$\mathrm{cm}$ taller than French, but still $3.3 \mathrm{~cm}$ shorter than Norwegian. The Dutch kept growing fast to be $177.5 \mathrm{~cm}$, as tall as Norwegian in 1960 (1940 birth cohort), 5.8 $\mathrm{cm}$ and $11.1 \mathrm{~cm}$, respectively taller than French and Portuguese. In 2000 (1980 birth cohort), the Dutch were $182.7 \mathrm{~cm}, 3 \mathrm{~cm}$ taller than Norwegians and $6.2 \mathrm{~cm}$ and $10.6 \mathrm{~cm}$, respectively taller in mean height than French and Portuguese (Figure 1) [3].

Until a few years ago, the author would take it for granted that people in Northern Europe were conspicuously taller in mean height than people in Southern Europe, possibly due to genetic differences. R. Steckel (1995) stated, stature is a net measure that captures the supply of inputs to health [4]. Since the mid-19th century, people in the Netherlands have been benefitted from a superior "supply of inputs to health", compared to other nations in Southern Europe and Northern Europe, as well. In human biology, substantial empirical research has been conducted to make up for a superior supply of inputs to health, with a majority consensus on the importance of high-quality protein (Baten and Blum, 2014; Grasgruber et al., 2020) [5] [6].

The author, based on years of investigations on the growth of children's height in Japan and South Korea in the past half century, in the capacity of a food economist, would like to introduce his conjectures on the importance of vegetables/fruit as "essential nutrients" in inputs to health [7] [8] [9] [10]. He discussed why Japanese children plateaued in height in the mid-1980s, while consumption of animal-sourced foods was still increasing. South Koreans kept increasing in height to overtake Japanese peers by $3-4 \mathrm{~cm}$ in the mid-2000s and then abruptly

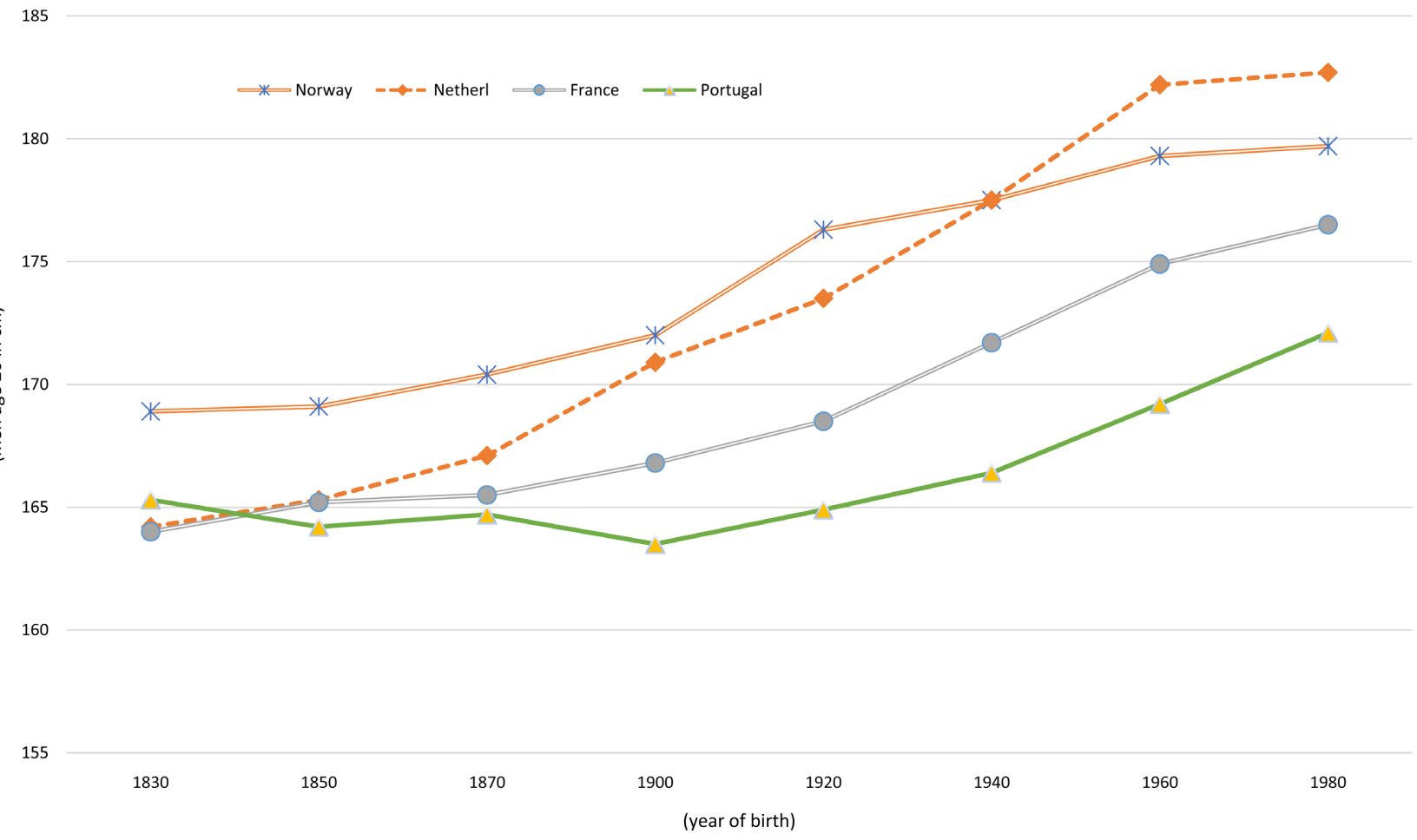

Figure 1. Changes in mean height of young men (age 20), France, Netherlands, Norway and Portugal, by birth year, 1830 to 1980. 
stopped growing taller afterward, even slightly shrank in height at the end of the 2010s. The Korean economy was in high prosperity and per capita consumption of animal products was still on the steady rise then.

\section{Data}

The government of the Netherland, the Central Bureau of Statistics (CBS) conducted large scale children's growth studies, five times after the end of WWII, 1952-1956, 1964-1966, 1978-1980, 1996-1997, and 2009 [11] [12] [13] [14]. The surveys covered the age range from zero to 21 years old, specifically in respect of stature. At the Asian side, there are two data sources, National Nutrition Surveys, which cover the age range from one to 25 years old, $26-29,30-39, \ldots$, every year from 1946 to 2020 in Japan [15]. The comparable survey was first conducted in 1998 in South Korea, followed by the $2^{\text {nd }}$ one in 2001, the $3^{\text {rd }}$ one in 2005 and every year since 2006 [16]. In this article, we use National School Health Statistics Surveys, which have been conducted by Department of Education on national bases every year for a long time, since 1900 in Japan [17] and $1960^{\star 1}$ in South Korea [18] ( ${ }^{*} 1$ : The data available for the author at this moment).

The School Surveys cover the ages for $1^{\text {st }}$ grade in primary school (6 years old in the first month of school year, April in Japan and March in Korea) to senior grade of high school (17 years old) and do not provide the data for the earlier years of life and post-adolescent years from 18 to 20. Examining the data from Nutrition Surveys, boys in Japan tend to grow another $1.0 \mathrm{~cm}$ taller after the age of 17, at the maximum ${ }^{* 2}$, whereas boys in the Netherlands grow another $2.0 \mathrm{~cm}$, before reaching 20 in age during the period of 1980 to 1997 ( ${ }^{*}$ : SD for age 17 and 18 in mean height in Japan average $5-7 \mathrm{~cm}$ in magnitude for the 1990s [15]).

The economy of Korea was devastated by the Korean War (1950-53) and it was only the mid-1960s, when the economy launched on normal progress. Due to the indigenous hard-working nationality combined with desires for higher education, Korean economy has achieved fast and steady developments. In terms of per capita GDP, however, Korea was one half the level of Japan in the mid-2000s [19], when Korean teens overtook Japanese peers in height by $3.0 \mathrm{~cm}$. Children in lower grades of primary school were $5-6 \mathrm{~cm}$ taller than Japanese peers in the end of the 2000s. Children in Korea, however, stopped growing taller shortly before 2010 and some signs of shrinking in height are noticed in the beginning of the 2020s, under economic prosperity (Table 1).

In the mid-1960s, boys at age 17 in the Netherlands were approximately $10 \mathrm{~cm}$ taller than their peers in Japan and South Korea. Again in 1980, boys in the Netherlands were approximately $15 \mathrm{~cm}$ taller than their peers in North-East Asia, that had steadily grown taller in height at all ages, implying that the Dutch boys had grown conspicuously faster in height from the mid-1960s to 1980. After the beginning of the 1980s, however, male children in the Netherlands ceased to grow taller at any age-stage. In 2009, for example, the Dutch boys at age 6 through 12 were more than $2 \mathrm{~cm}$ shorter than their Korean peers (Table 2). If ${ }^{* 3}$ 
Table 1. Changes in mean height of school boys by age, Japan and South Korea, 1965 to 2017. (cm)

\begin{tabular}{ccccccccccccc}
\hline \multicolumn{1}{c}{} & \multicolumn{10}{c}{ Japan } \\
\hline Age & 1965 & 1970 & 1975 & 1980 & 1985 & 1990 & 1995 & 2000 & 2005 & 2010 & 2015 & 2017 \\
\hline 6 & 113.4 & 114.5 & 115.2 & 115.7 & 116.4 & 116.8 & 116.8 & 116.7 & 116.7 & 116.7 & 116.5 & 116.5 \\
7 & 118.8 & 120.0 & 120.8 & 121.3 & 122.1 & 122.5 & 122.6 & 122.4 & 122.5 & 122.6 & 122.5 & 122.5 \\
11 & 138.6 & 140.4 & 141.9 & 142.8 & 143.3 & 144.4 & 144.9 & 145.3 & 145.1 & 145.0 & 145.2 & 145.1 \\
12 & 144.7 & 147.0 & 148.6 & 149.5 & 150.1 & 151.5 & 152.0 & 152.8 & 152.6 & 152.4 & 152.6 & 152.7 \\
16 & 165.7 & 166.9 & 167.9 & 168.8 & 169.3 & 169.6 & 170.1 & 170.1 & 170.0 & 169.9 & 169.8 & 169.9 \\
17 & 166.7 & 167.9 & 168.8 & 169.6 & 170.2 & 170.5 & 170.9 & 170.9 & 170.8 & 170.7 & 170.7 & 170.6 \\
\hline
\end{tabular}

Sources: school health examination surveys, ministry of education, various issues [17].

\begin{tabular}{cccccccccccccc}
\hline \multicolumn{10}{c}{ S. Korea } \\
\hline Age & 1965 & 1970 & 1975 & 1980 & 1985 & 1990 & 1995 & 2000 & 2005 & 2010 & 2015 & 2017 \\
\hline 6 & 111.9 & 112.9 & 112.9 & 115.4 & 116.2 & 117.7 & 119.0 & 120.2 & 121.0 & 121.8 & 120.5 & 120.6 \\
7 & 115.2 & 117.6 & 118.5 & 120.5 & 121.9 & 123.0 & 124.7 & 125.9 & 126.8 & 127.7 & 125.8 & 125.7 \\
11 & 131.4 & 134.5 & 136.1 & 139.6 & 141.6 & 143.7 & 145.7 & 147.9 & 149.4 & 150.4 & 149.0 & 149.4 \\
12 & 141.8 & 143.7 & 143.2 & 145.2 & 147.6 & 149.7 & 152.0 & 154.8 & 156.9 & 158.0 & 156.7 & 157.2 \\
16 & 161.9 & 163.9 & 164.3 & 165.9 & 167.3 & 168.3 & 170.3 & 172.1 & 172.8 & 173.1 & 172.7 & 172.9 \\
17 & 163.8 & 166.1 & 166.1 & 167.3 & 168.9 & 169.7 & 171.0 & 172.9 & 173.7 & 173.7 & 173.4 & 173.5 \\
\hline
\end{tabular}

Sources: school health examination surveys, department of education, various issues [18].

Table 2. Secular changes in mean height of boys by selected age, NLD, JP, and KOR, 1955,1965,1980,1997, and 2009. (cm)

\begin{tabular}{|c|c|c|c|c|c|c|c|c|c|c|c|c|c|c|}
\hline \multirow{2}{*}{ age } & \multicolumn{2}{|c|}{1955} & \multicolumn{3}{|c|}{1965} & \multicolumn{3}{|c|}{1980} & \multicolumn{3}{|c|}{1997} & \multicolumn{3}{|c|}{2009} \\
\hline & NLD & $\mathrm{JP}$ & NLD & $\mathrm{JP}$ & KOR & NLD & $\mathrm{JP}$ & KOR & NLD & $\mathrm{JP}$ & KOR & NLD & $\mathrm{JP}$ & KOR \\
\hline $6 y$ & 115.7 & $\begin{array}{l}109.9 \\
(-5.8)\end{array}$ & 117.8 & $\begin{array}{l}113.0 \\
(-4.8)\end{array}$ & $\begin{array}{l}111.9 \\
(-5.9)\end{array}$ & 121.5 & $\begin{array}{l}115.7 \\
(-5.8)\end{array}$ & $\begin{array}{l}115.4 \\
(-6.1)\end{array}$ & 120.1 & $\begin{array}{l}116.7 \\
(-3.4)\end{array}$ & $\begin{array}{l}119.5 \\
(-0.6)\end{array}$ & 119.9 & $\begin{array}{l}116.7 \\
(-3.2)\end{array}$ & $\begin{array}{l}121.9 \\
(+2.0)\end{array}$ \\
\hline $12 \mathrm{y}$ & 147.5 & $\begin{array}{l}138.5 \\
(-9.0)\end{array}$ & 149.6 & $\begin{array}{l}144.1 \\
(-5.5)\end{array}$ & $\begin{array}{l}141.8 \\
(-7.8)\end{array}$ & 154.1 & $\begin{array}{l}149.5 \\
(-4.4)\end{array}$ & $\begin{array}{l}145.2 \\
(-8.9)\end{array}$ & 154.0 & $\begin{array}{l}152.4 \\
(-1.6)\end{array}$ & $\begin{array}{l}153.1 \\
(-0.9)\end{array}$ & 155.7 & $\begin{array}{l}152.5 \\
(-2.7)\end{array}$ & $\begin{array}{l}157.9 \\
(+2.7)\end{array}$ \\
\hline $17 \mathrm{y}$ & 173.5 & $\begin{array}{c}163.2 \\
(-10.3)\end{array}$ & 176.1 & $\begin{array}{l}166.4 \\
(-9.7)\end{array}$ & $\begin{array}{c}163.8 \\
(-12.3)\end{array}$ & 182.3 & $\begin{array}{c}169.6 \\
(-12.7)\end{array}$ & $\begin{array}{c}167.3 \\
(-15.0)\end{array}$ & 181.3 & $\begin{array}{c}170.9 \\
(-10.4)\end{array}$ & $\begin{array}{l}171.9 \\
(-9.4)\end{array}$ & 181.0 & $\begin{array}{c}170.7 \\
(-12.3)\end{array}$ & $\begin{array}{l}173.8 \\
(-7.2)\end{array}$ \\
\hline
\end{tabular}

Sources: referring to [11] [12] [13] [14]. Figures in parenthese denote differences from the Dutch boys in the same year of observation.

Korean children in adolescence had kept growing in height as fast as some 10 years ago, from the mid-1990s through the mid-2000s ( ${ }^{\star} 3$ : not the unrealistic premise), the Dutch boys would not have been overwhelmingly taller than boys 
in South Korea. In the following sections, the author will discuss why Korean children suspended growing taller since the mid-2000s, while per capita GDP kept rising and per capita consumption of animal-sourced foods increased steadily (in the later section). The author senses important similarities between the Dutch and the Korean peers in respect of stature developments, which may deserve in-depth analyses by the professional biologists.

\section{Children in Korea Declining in Height Growth Velocities over School Years in the Past Two Decades}

As we have observed in Table 1, Korean teens at age 17 were $171.0 \mathrm{~cm}$ in mean height, only $0.1 \mathrm{~cm}$ taller than Japanese peers in 1995 but grew to $173.7 \mathrm{~cm}$ in mean height, $2.9 \mathrm{~cm}$ taller than Japanese peers in 2005. One may perceive that school boys in Korea grew distinctly faster in height velocity than Japanese peers from the mid-1990s to the mid-2000s.

Biologically, one born in 1980, for example, grew to 1 year old on birthday in 1981,2 years old in 1982, ..., 6 years old in 1986, ..., 17 years old in 1997. No one grows instantly from 6 years old in 1986 to 17 years old in the same year of 1986. One aged from zero in age in 1980 to 6 years old in 1986, and 17 years old in 1997 , subject to changes in "supply of inputs to health" prevailed from 1980 to 1997 , to varied degrees in the changing socio-economic environments, not dominantly existing in a single year, 1980 or 1997. In determining biological growth velocities, say from 6 years to 17 years of age, it should be natural to keep track of birth cohorts, instead of comparing rising ages in the given same year. To repeat, the 17 years old children in 1991 were born in 1974, 6 years old in 1980, ..., 16 years old in 1990.

Figure 2 demonstrates changes in growth velocities from 6 to 17 years of age over the period from 1991 to $2017^{\star 4}$, in Japan and South Korea ( ${ }^{\star} 4$ : to be exact, moving average 1990-1992 to 2016-2018). At the beginning of the survey period, children both in Japan and South Korea had grown nearly equal in velocity, approximately at $55.0 \mathrm{~cm}$. Children in Japan then started to decline gradually to 54.0 $\mathrm{cm}$ in the end of the period, whereas Korean peers rose to $55.5 \mathrm{~cm}$ in the early-2000s and then turned to decline straight to $52.2 \mathrm{~cm}$ in 2017. The author was impressed to notice that the youngest school children, $1^{\text {st }}$ graders in primary school in Korea grew steadily much faster in mean height than their Japanese peers, to overtake Japanese peers slightly in 1997 and then as much as $121.3-116.6=4.7 \mathrm{~cm}$ in $2017^{\star 5}$ ( ${ }^{*}$ : 17 years old in 2017 was 6 years old in 2006).

Do children tend to grow slower in height in their adolescence, if they have grown faster in their infancy, or before they enter primary schools: the opposite case of "catching-up"? The author has personally observed that taller boys in primary school have proved shorter when graduating from high school and vice versa. When we observe the case of the Dutch children, as compared to the Asian children, they grow substantially faster in their adolescence, from 12 to 17 , as shown in Table 2. Are these differences attributable to genetics? 


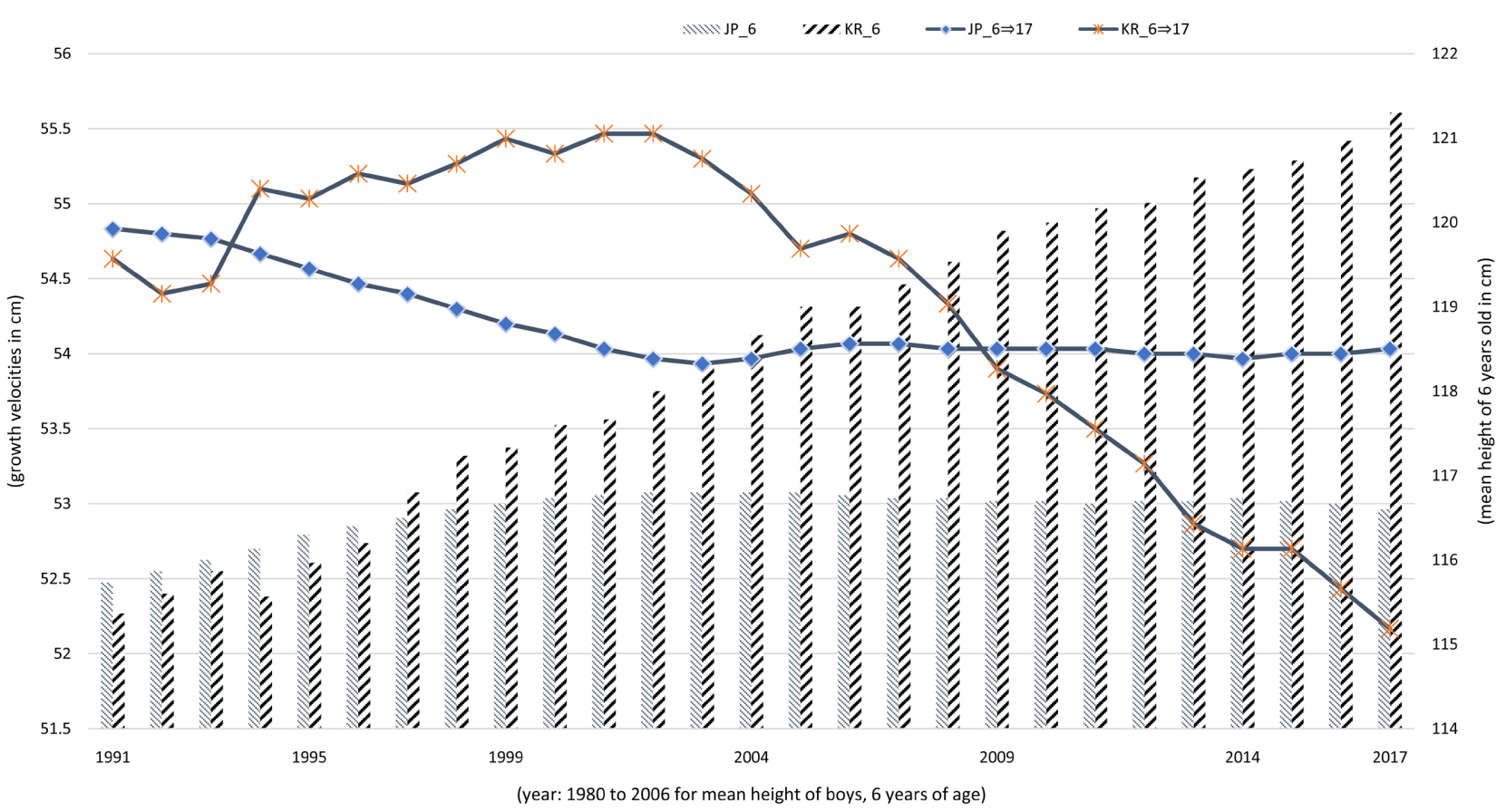

Figure 2. Secular changes of mean height of 1st graders in primary school and growth velocities from 6 to 17 years old, Japanese and S. Krean school boys, over the past three decades.

\section{Korean School Boys Started to Fall in Growth Velocities in the Early 2000s, When the Economy Prospered}

People in South Korea are widely known for Kimchi, fermented vegetables in diet. When South Korea was a quarter in per capita GDP of Japan in the early-1990s, per capita supply of vegetables was $196.1 \mathrm{~kg} / \mathrm{year}$, nearly $80 \%$ greater and per capita supply of rice was $101.8 \mathrm{~kg} /$ year, nearly $60 \%$ greater, respectively than in Japan, whereas per capita meat and milk was $46.4 \mathrm{~kg}$, below $40.0 \%$ of that of Japan. When children in Korea caught-up Japanese peers in mean height and overtook Japanese peers by $3-4 \mathrm{~cm}$ in height in the early-2000s, per capita supply of meat and milk in South Korea was $73.1 \mathrm{~kg} /$ year, $60 \%$ the level of Japan. In terms of per capita supply of vegetables, however, South Korea was $229.6 \mathrm{~kg}$, twice as large as Japan in 2000 (FAOSTAT [20]).

The author was provided access to Household Income and Expenditure Surveys, classified by age groups of household head, Statistics Korea, 1990 to 2019 [21] (Courtesy: Dr. S. Kim, KREI [22]). The Surveys provide age composition of household by $\mathrm{HH}$ age groups, such that household headed by those in their 40 44 contained 0.466 persons in age group 0 to $9,0.766$ persons in 10 to $14,0.533$ persons in 15 to $19, \ldots$, respectively in 1999 , for example. With this valuable information, it was technically possible for the author to derive per capita household expenditures by age groups of household members on selected food groups, vegetables, meats, etc. in selected years from 1990 to 2019, by means of the TMI model [23].

Table 3 and Table 4 provide changes in household monthly expenditures by 
Table 3. Changes in per capita monthly at-home expenditures on vegetables, by age of household members, 1990 to 2019. (In 2010 Won)

\begin{tabular}{cccccccc}
\hline Age/Year & $1990-1991$ & $1995-1996$ & $2000-2001$ & $2005-2006$ & $2010-2011$ & $2014-2015$ & $2017-2019$ \\
\hline $0-9$ & 17,857 & 12,261 & 7352 & 4505 & 2519 & 2847 & 1856 \\
$10-14$ & 18,593 & 13,452 & 8233 & 6884 & 3070 & 2861 & 2210 \\
$15-19$ & 18,504 & 13,693 & 8805 & 7927 & 3789 & 3168 & 2828 \\
$20-29$ & 19,801 & 16,414 & 10,563 & 10,568 & 5558 & 4823 & 4915 \\
$30-39$ & 26,309 & 25,237 & 15,037 & 16,541 & 9680 & 9486 & 9998 \\
$40-49$ & 34,428 & 34,267 & 20,639 & 23,888 & 14,560 & 13,838 & 14,925 \\
$50-59$ & 35,876 & 39,010 & 24,140 & 30,639 & 20,062 & 18,889 & 21,914 \\
$60-$ & 34,134 & 38,357 & 25,114 & 32,786 & 23,314 & 22,884 & 28,603 \\
\hline
\end{tabular}

Sources: derived by the author, from Household Income and Expenditure Surveys [21], by means of the TMI model.

Table 4. Changes in per capita monthly at-home expenditures on meats, by age of household members, 1990 to 2019. (In 2010 Won)

\begin{tabular}{cccccccc}
\hline Age/Year & $1990-1991$ & $1995-1996$ & $2000-2001$ & $2005-2006$ & $2010-2011$ & $2014-2015$ & $2017-2019$ \\
\hline $0-9$ & 11,608 & 16,155 & 15,490 & 9125 & 10,165 & 12,286 & 13,285 \\
$10-14$ & 11,949 & 16,997 & 16,270 & 10,180 & 11,153 & 13,074 & 13,373 \\
$15-19$ & 10,780 & 15,078 & 15,857 & 10,367 & 11,064 & 13,090 & 12,718 \\
$20-29$ & 12,651 & 17,641 & 17,142 & 11,018 & 11,255 & 12,995 & 12,249 \\
$30-39$ & 20,255 & 29,725 & 23,091 & 14,675 & 15,713 & 17,387 & 18,739 \\
$40-49$ & 26,801 & 38,985 & 29,316 & 20,220 & 22,084 & 23,026 & 25,413 \\
$50-59$ & 28,026 & 40,791 & 31,279 & 22,034 & 22,481 & 24,691 & 27,653 \\
$60-$ & 25,911 & 40,027 & 30,048 & 21,754 & 19,811 & 21,585 & 25,673 \\
\hline
\end{tabular}

Sources: derived by the author from HIES [21], various issues, the TMI model.

age groups of household members on vegetables, including processed vegetables like Kimchi, from 1990 to 2019 (1990-1991 to 2017-2019, two-year averages), and meats, including processed meats like ham, sausages, in 2010 constant Won. In the tables for vegetables and meats, the younger members of household have proved spending less than the older members in their $40 \mathrm{~s}$ and $60 \mathrm{~s}$, partly because female family members in $40 \mathrm{~s}$ to $60 \mathrm{~s}$ tend to eat less away from home either in Japan or South Korea. The most of all, the author was stunned to discover that children under 20 years of age have reduced drastically their at-home consumption of vegetables over the past three decades in South Korea: turning away from vegetables by the young, equivalent to wakamono no kudamono-banare ("steering away from fruit by the young"), announced by the Japanese government's 1994 White Paper on Agriculture [24]. The author and his colleagues es- 
timated changes in per capita household consumption of fruit by age groups in Japan from the early 1970s to the early 2010s, by refined econometric models to confirm the 1994 White Paper (Mori and Inaba; Tanaka, Mori, and Inaba; Mori and Stewart; etc.) [23] [25] [26] (Table 5). Mori hypothesized that a steady and drastic reduction of fruit consumption by the young in growing ages may have caused the stagnation of children's height growth since the late-1980s observed in Japan (Mori, 2018; 2020; 2021; etc.) [27] [28] [29].

In 1990-1991, teens in Korea spent 18,000 Wons (in 2010 constant Won) on vegetables, about a half of grown-up adults. They started to reduce vegetable consumption as early as the mid-1990s, further halved it in the early-2000s and in the end of the 2010s they spent as little as $10 \%$ as those in their $50 \mathrm{~s}$. The young in Japan steered away from fruits in the mid-1970s. In the case of Japan, increases in animal protein did not result in increasing human height, due to insufficient consumption of "essential nutrients" [1], fruit. Steady increases in animal protein, financed by rising per capita GDP, ceased to result in increasing height of adolescents in South Korea in the past two decades, due to insufficient supply of “essential nutrients", vegetables.

\section{Plateauing of the Dutch in Height in the Past Three Decades: The Lessons from South Korea?}

In human biology, it has been widely accepted that animal sourced foods, or animal protein should be the key-determinants of human height (Grassgruber, 2020; etc.) [6]. With regard to supply of animal products, changes in per capita national supply of protein from animal products are shown in Table 6. The Netherlands has not been substantially larger in supply of animal products than the rest of the Northern European countries since the 1960s. The audience may need to recognize that simple per capita supply/consumption of animal-sourced foods of the entire population does not identify changes in consumption of any food

Table 5. Changes in per capita at-home consumption of fresh fruit by age groups, 1971 to 2010, Japan. (kg/year)

\begin{tabular}{cccccccc}
\hline & 1971 & 1980 & $1985-1986$ & 1990 & $1995-1996$ & 2000 & $2008-2010$ \\
\hline $0-9$ & 36.3 & 26.5 & 15.2 & 8.9 & 4.7 & 2.3 & 3.0 \\
$10-19$ & 45.6 & 30.5 & 20.1 & 14.9 & 9.4 & 5.7 & 4.7 \\
$20-29$ & 48.3 & 31.5 & 23.4 & 16.8 & 15.1 & 11.8 & 10.5 \\
$30-39$ & 46.1 & 43.8 & 36.6 & 30.4 & 23.6 & 21.8 & 16.4 \\
$40-49$ & 51.0 & 52.6 & 48.5 & 44.9 & 37.2 & 33.4 & 22.6 \\
$50-59$ & 54.4 & 59.9 & 56.6 & 54.0 & 50.5 & 48.5 & 36.4 \\
$60-$ & 42.9 & 56.4 & 60.4 & 61.2 & 60.4 & 63.3 & 57.1 \\
Grnd-ave & 45.6 & 41.6 & 36.4 & 33.8 & 31.5 & 31.1 & 28.9 \\
\hline
\end{tabular}

Sources: derived by the author from FIES [30], various issues, the TMI model. 
products, specifically by children in growing ages, as we have seen above. One can notice, however, that per capita supply of vegetables in the Netherlands has been appreciably larger than other North-European counties in the 1960-1980s, but conspicuously smaller than South Korea, Table 7. When the FAOSTAT estimation system was revised in 2014, it was discovered that the Netherlands was distinctly smaller than Denmark and Sweden and only 30\% the level of South Korea in per capita supply of vegetables.

Table 6. Changes in per capita protein from animal products, Netherlands and selected European countries, and South Korea, 1961-1962 to 2000 and 2004 to 2018. (gr/day)

\begin{tabular}{cccccccc}
\hline & NLD & DNK & NOR & FRA & PRT & SWE & KOR \\
\hline $1961-2$ & 52 & 46 & 52 & 58 & 27 & 56 & 6 \\
1970 & 59 & 47 & 53 & 65 & 35 & 58 & 9 \\
1980 & 65 & 56 & 65 & 76 & 35 & 67 & 18 \\
1990 & 65 & 70 & 60 & 78 & 54 & 64 & 27 \\
2000 & 75 & 65 & 65 & 78 & 68 & 68 & 37 \\
2010 & 73 & 67 & 65 & 71 & 70 & 71 & 44 \\
2014 & 73 & 69 & 65 & 64 & 69 & 71 & 46 \\
2015 & 73 & 71 & 67 & 64 & 70 & 71 & 48 \\
2016 & 72 & 76 & 66 & 64 & 71 & 70 & 49 \\
2017 & 64 & 76 & 68 & 64 & 72 & 69 & 51 \\
2018 & 70 & 80 & 68 & 64 & 74 & 67 & 52 \\
\hline
\end{tabular}

Sources: FAOSTAT, food balance sheets, old methodolody for 1961-2010, and new methodology for 2014-2018 [20]. Notes: 1970 to 2010 denote 3 year moving averages.

Table 7. Changes in per capita vegetables, Netherlands and selected European countries and South Korea, 1961-1962 to 2000 and 2004 to 2018. (kg/year)

\begin{tabular}{cccccccc}
\hline & NLD & DNK & NOR & FRA & PRT & SWE & KOR \\
\hline $1961-2$ & 76 & 41 & 44 & 149 & 95 & 34 & 76 \\
1970 & 84 & 46 & 51 & 134 & 133 & 37 & 107 \\
1980 & 76 & 61 & 56 & 116 & 112 & 47 & 206 \\
1990 & 72 & 73 & 58 & 128 & 166 & 64 & 196 \\
2000 & 98 & 91 & 64 & 109 & 191 & 75 & 230 \\
2010 & 83 & 120 & 76 & 103 & 186 & 91 & 212 \\
2014 & 57 & 97 & 75 & 95 & 143 & 89 & 210 \\
2015 & 64 & 93 & 72 & 93 & 168 & 90 & 192 \\
2016 & 66 & 97 & 75 & 101 & 158 & 90 & 185 \\
2017 & 64 & 101 & 73 & 102 & 156 & 86 & 194 \\
2018 & 58 & 104 & 71 & 99 & 120 & 83 & 201 \\
\hline
\end{tabular}

Sources: the same as Table 6. Notes: the same as Table 6. 
According to the author's three decades' endeavor in cohort analyses of food consumption (Mori et al., Declining orange consumption in Japan, ERS/USDA; Mori, Inaba, and Dyck, 2016; etc.) [31] [32]. "Structural changes" in selected food products, fruits, fish, meat and so force, are commonly initiated by the newer cohorts in the population [33]. Intuitively, the author suspects that the decline in vegetable consumption in the Netherlands may have been initiated by the younger cohorts of the population. If fast foods, like McDonald's, are more prevalent in the Netherlands, than other countries in northern Europe, one may be safe to assume that the young in the Netherlands have been less "varied" in diet, a slice of onions/tomatoes with animal meats, in "Big-Mac", for example (USA Today, etc.) [34].

\section{Conclusions}

Despite substantially lower per capita GDP, school children in South Korea caughtup with Japanese peers in height in the 1990s and overtook them by $3-4 \mathrm{~cm}$ in the early 2000s. The economy in Korea still prospered and per capita meat consumption kept increasing toward the end of the 2010s, but children abruptly stopped growing taller after the mid-2000s. More than a decade ago, Korean in the younger age groups, school children started to turn away from vegetables (Kimchi) and they ate only $10 \%$ of vegetables eaten by older adults in their $50 \mathrm{~s}$ at the end of the 2010s. Higher consumption of animal protein did not result in increasing children's height, due to insufficient consumption of "essential nutrients", vegetables. Inputs to health, only before one reaches the age of maturity, would result in human height.

The Dutch may have nearly attained genetic potentials in the mass. The author suspects, however, that per capita consumption of vegetables by children in growing ages in the Netherlands may have been declining appreciably in the near past, since the 1990s. "The supply of inputs to health" of children in growing ages requires specific attention. In the quantitative studies of human biology, per capita consumption of specific food products, like milk, pork, or vegetables of the total population of the nations and/or the chosen period has been used to identify the key determinants of child height development. It is common that the newer generations (children in growing ages) should eat in a significantly different manner from the rest of the population.

\section{Acknowledgements}

Thanks to the reviewers' comments, the author could have expressed his views with less hesitance.

The author is grateful to Dr. Howard Elliott, the former Deputy General, ISNAR, The Hague, Prof. Tim Cole, UCL, London and Prof. Yvonne Shonbeck, Leiden for proving valuable data and insights.

\section{Conflicts of Interest}

The author declares no conflicts of interest. 


\section{References}

[1] Blum, M. (2013) Cultural and Genetic Influences on the 'Biological Standard of Living. Historical Methods, 46, 19-30. https://doi.org/10.1080/01615440.2012.703952

[2] Mori, H. (2018) Secular Trends in Child Height in Japan and South Korea: Consumption of Animal Protein and 'Essential Nutrient'. Food and Nutrition Sciences, 9, 1458-1471. https://doi.org/10.4236/fns.2018.912106

[3] Roser, M., Appel, C. and Ritchie, H. (2019, May) Human Height. Our World in Data. https://ourworldindata.org/human-height

[4] Steckel, R. (1995) Structure and the Standard of Living. Journal of Economic Literature, 33, 1903-1940.

[5] Baten, J. and Blum, M. (2014) Why Are You Tall While Others Are Short? Agricultural Production and Other Proximate Determinants of Global Heights. European Review of Economic History, 18, 144-165. https://doi.org/10.1093/ereh/heu003

[6] Grasgruber, P. and Hrazdira, E. (2020) Nutritional and Socio-Economic Predictors of Adult Height in 152 World Populations. Economics and Human Biology, 20, Article ID: 100848. https://doi.org/10.1016/j.ehb.2020.100848

[7] Mori, H. (2017) Stature: Key Determinants of Positive Height Trends-The Case of Japan and South Korea. Monthly Bulletin of Social Sciences of Senshu University, 21-40.

[8] Mori, H. (2019) Why Did Japanese Children Cease to Grow Taller in Height in the Midst of a Booming Economy in Contrast with South Korean Youth? Annual Bulletin of Social Science of Senshu University, 223-240.

[9] Mori, H. and Kim, S. (2020) Child Height and Food Consumption in Japan in the Past Century in Comparison with South Korea: Animal Protein and Other Essential Nutrients. Global Journal of Medical Research: Nutrition \& Food Sciences, 20, 1-9. https://doi.org/10.34257/GJMRLVOL20IS1PG1

[10] Mori, H. (2021) Secular Changes in Mean Height of Children in Japan and South Korea-Suspension in Height Increase and BMI. International Journal of Diabetes and Endocrinology, 112, 1-5. https://doi.org/10.46715/ijde2021.05.1000112.

[11] De Wijn, J.F. and De Haas, J.H. (1960) Vrerbandelingen. Nederlands Institut voor Praeventieve, Geneekunde.

[12] Van Wieringen, J.C., Wafelbakker, F., Verbrugge, H.P. and De Haas, J.H. (1971) Growth Diagrams 1965 Netherlands. Wolters-Noordhoff, Groningen.

[13] Fredrics, M., Van Buuren, S., Burgmeijer, R.J.F., Meulmeester, J.F., Beuker, R.J., Brugman, E., et al. (2000) Continuing Positive Secular Growth Change in the Netherlands, 1955-1997. Pediatric Research, 47, 310-323. https://doi.org/10.1203/00006450-200003000-00006

[14] Shonbeck, Y., Talma, H., van Dommelen, P., Bakker, B., Buitendijk, S.E., HiraSing, R.A., et al. (2013) The World's Tallest Has Stopped Growing Taller: The Height of Dutch Children from 1955 to 2009. Pediatric Research, 73, 371-377.

https://doi.org/10.1038/pr.2012.189

[15] Japanese Government, Ministry of Labor and Welfare (1946-2020) National Nutrition Surveys. Ministry of Labor and Welfare, Tokyo.

[16] Republic of Korea, Korea Centers for Disease Control and Prevention (1998, 2001, 2005, and Following Issues) Korea National Health and Nutritional Examination Survey. Korea Centers for Disease Control and Prevention, Cheongju.

[17] Japanese Government, Ministry of Education. National School Health Examination 
Statistical Surveys. Various Issues. Ministry of Education, Japan.

[18] Republic of Korea, Department of Education, Center for Educational School Health Examination Surveys. Statistical Yearbook of Education. Various Issues, Center for Educational School Health Examination Surveys, Korea.

[19] World Bank. National Accounts Data.

[20] FAOSTAT (2014) Food Balance Sheets, Old Methodologies and New Methodologies.

[21] Republic of Korea, Statistics Korea. Household Income and Expenditure Surveys. Various Issues, Statistics Korea, Sejong.

[22] Kim, S. (2021) Research Fellow. Korea Rural Economic Institute, Jeollanam-do.

[23] Tanaka, M., Mori, H. and Inaba, T. (2004) Re-Estimating Per Capita Individual Consumption by Age from Household Data. Japanese Journal of Rural Economics, 6, 20-30. https://doi.org/10.18480/jire.6.20

[24] Japanese Government, Ministry of Agriculture (1995) 1994 White Paper on Agriculture. Japanese Government, Ministry of Agriculture, Tokyo.

[25] Mori, H. and Toshio, I. (1997). Estimating Individual Fresh Fruit Consumption by Age. Journal of Rural Economics, 69, 175-185.

[26] Mori, H. and Stewart, H. (2011) Cohort Analysis: Ability to Predict Future Consumption-The Case of Fresh Fruit in Japan and Rice in Korea, Annual Bulletin of Social Sciences of Senshu University, 153-173.

[27] Mori, H. (2016) Secular Trends in Height of Children in Japan-Food Consumption Perspectives, Economic Bulletin of Senshu University, 67-84. (in Japanese)

[28] Mori, H. (2020) Secular Changes in Boys' Height in South Korea: Comparison with Japan, Particularly with Respect to Growth Velocity. Journal of Food and Nutrition, 6, 1-7.

[29] Mori, H. (2021) Changes in Children's Height in Japan and South Korea in the Past Half Century: The Roles of Fruit/Vegetables on Top of Protein. European Journal of Applied Sciences, 9, 118-126. https://doi.org/10.14738/aivp.95.10971

[30] Japanese Government, Bureau of Statistics. Family Income and Expenditure Surveys. Various Issues, Tokyo.

[31] Mori, H., Clason, D., Ishibashi, K., Gorman, W.D. and Dyck, J. (2009) Declining Orange Consumption in Japan: Generational Changes or Something Else? Economic Research Report No. 71, United States Department of Agriculture, Washington DC.

[32] Mori, H., Inaba, T. and Dyck, J. (2015) Accounting for Structural Changes in Demand for Foods in the Presence of Age and Cohort Effects: The Case of Fresh Fish in Japan. Evolutionary and Institutional Economics Review, 13, 363-370. https://doi.org/10.1007/s40844-016-0056-Z

[33] Mori, H. (2020) Structural Changes in Food Consumption and Human Height in East Asia. Lambert Academic Publishing, Berlin, 1-156.

[34] USA TODAY (2021, September 20) The Dutch Are the World Tallest People. But They're Getting Shorter. Study Shows, Wyatte Grantham-Phillips. 